\title{
Interactive comment on "Characterising
} Mass-resolved Mixing State of Black Carbon in Beijing Using a Morphology-Independent Measurement Method" by Chenjie Yu et al.

\section{Anonymous Referee \#3}

Received and published: 9 October 2019

The comment was uploaded in the form of a supplement:

https://www.atmos-chem-phys-discuss.net/acp-2019-428/acp-2019-428-RC2-

supplement.pdf

Interactive comment on Atmos. Chem. Phys. Discuss., https://doi.org/10.5194/acp-2019-428, 2019. 